SHS Web of Conferences 6, 01013 (2014)

DOI: $10.1051 /$ shsconf / 20140601013

(C) Owned by the authors, published by EDP Sciences, 2014

\title{
On Capability Approach, Poverty and Corruption
}

\author{
Hu Daojiu ${ }^{\mathrm{a}}$ \\ Business School of Shanghai University of Electric Power, 200090 Shanghai, China.
}

\begin{abstract}
The core of development is to face up with the challenge of the issue of poverty, which directly is associated with the ultimate goal of social, political and economic development. If the poverty has not been properly handled, development will be inefficient and unsustainable. This paper briefly indicates the main idea of Amartya Sen's capability approach, then utilizing the approach to analyze poverty and the bottleneck in dealing such issues. It illustrates the inter-relationship of capability, poverty and corruption, and demonstrates that corruption is both the cause and the consequence of poverty and the failure of capability. When there corruption comes, the essential power to alleviate and eliminate poverty such as political accountability, transparency, engagement and openness are all spoiled and even wiped off. Political accountability, transparence, engagement are of great importance to both anti-corruption and poverty and promotion of capability. Economic aid for the poor and needy should be reinforced by fostering and promoting the capability of the poor and needy, so that the purpose of eliminating poverty and corruption could be achieved.
\end{abstract}

Keywords. capability approach; poverty; corruption

\section{Introduction}

The essential problem of development is to face the challenge of the issue of poverty, which directly is associated with the ultimate goal of social, political and economic development. If poverty has not been properly solved, development will be inefficient and unsustainable. In order to deal with the poverty during the process of development, it is important to probe the conception of poverty and the reasons concerning poverty. Understanding poverty from the perspective of capability approach, it is helpful for us to recognize the origin and cause of poverty, to promote capability of the poor and needy, and to prevent the serious corruption accompanied with poverty during the total process of development.

Nowadays, the majority of developing countries are lack of substantial development. Due to inadequate understanding of conquering poverty, the IOs, NGOs, and global governments didn't view the poverty, capability failure and corruption as an integrated entity. As for lack of integrated policy and collective efforts, combating corruption, overcoming poverty and promoting capability of global citizens are inefficient. More than half of world populations are still suffering from the poor.

\section{Conception of capability approach}

${ }^{\mathrm{a} C}$ Corresponding author: hudaojiu@yahoo.com.cn

This is an Open Access article distributed under the terms of the Creative Commons Attribution License 2.0, which permits unrestricted use, distribution, and reproduction in any medium, provided the original work is properly cited. 
Amartya Sen [17][18]defines the basic building blocks of the Capability Approach, beginning with the concept of "functionings". Functionings are what individuals may value doing or being. This includes basic functionings such as literacy and avoiding preventable diseases, as well as more developed activities such as taking part in community life and enjoying social self-respect. A person's "capability set" refers to the bundle of all the functionings from which a person has the freedom to choose. In Sen's Capability Approach, "expansion of freedom is viewed as both (1) the primary end and (2) the principal means of development"'[18]. In particular, Sen identifies five instrumental freedoms that are valuable not only as ends in themselves, but also as the primary means of development: political freedoms, economic facilities, social opportunities, transparency guarantees, and protective security.

The capability approach is a broad normative framework for the evaluation and assessment of individual well-being and social arrangements, the design of policies, and proposals about social change in society. It is used in a wide range of fields, most prominently in development studies, welfare economics, social policy and political philosophy. [1]It can be used to evaluate several aspects of people's well-being, such as inequality, poverty, the well-being of an individual or the average well-being of the members of a group.[3] It can also be used as an alternative evaluative tool for social cost-benefit analysis, or as a framework within which to design and evaluate policies, ranging from welfare state design in affluent societies, to development policies by governments and nongovernmental organizations in developing countries. In academia, it is being discussed in quite abstract and philosophical terms, but is also used for applied and empirical studies. The core characteristic of the capability approach is its focus on what people are effectively able to do and to be; that is, on their capabilities.[4] This contrasts with philosophical approaches that concentrate on people's happiness or desire-fulfilment, or on income, expenditures, or consumption. Some aspects of the capability approach can be traced back to, among others, Aristotle, Adam Smith, and Karl Marx. The approach in its present form has been pioneered by the economist and philosopher Amartya Sen and has more recently been significantly further developed by the philosopher Martha Nussbaum, and a growing number of other scholars.[5]

Sen argues that our evaluations and policies should focus on what people are able to do and be, on the quality of their life, and on removing obstacles in their lives so that they have more freedom to live the kind of life that, upon reflection, they have reason to value. according to the capability approach, the ends of well-being, justice and development should be conceptualized in terms of people's capabilities to function; that is, their effective opportunities to undertake the actions and activities that they want to engage in, and be whom they want to be.[18][21] These beings and doings, which Sen calls functionings, together constitute what makes a life valuable. Functionings include working, resting, being literate, being healthy, being part of a community, being respected, and so forth. The distinction between achieved functionings and capabilities is between the realized and the effectively possible; in other words, between achievements on the one hand, and freedoms or valuable options from which one can choose on the other. What is ultimately important is that people have the freedoms or valuable opportunities (capabilities) to lead the kind of lives they want to lead, to do what they want to do and be the person they want to be. [8][9] Once they effectively have these substantive opportunities, they can choose those options that they value most.

The capability approach evaluates policies according to their impact on people's capabilities. It asks whether people are being healthy, and whether the means or resources necessary for this capability are present, such as clean water, access to doctors, protection from infections and diseases, and basic knowledge on health issues. It asks whether people are well-nourished, and whether the conditions for this capability, such as having sufficient food supplies and food entitlements, are being met. It asks whether people have access to a high-quality educational system, to real political participation, to community activities that support them to cope with struggles in daily life and that foster real friendships. For some of these capabilities, the main input will be financial resources and economic production, but for others it can also be political practices and institutions, such as the effective guaranteeing and protection of freedom of thought, political participation, social or cultural practices, social structures, social institutions, public goods, social norms, traditions and habits. The capability approach thus covers all dimensions of human well-being.[10] Development, well-being, 
and justice are regarded in a comprehensive and integrated manner, and much attention is paid to the links between material, mental and social well-being, or to the economic, social, political and cultural dimensions of life. The definition of capability, then, combines functioning and freedom. But the capability approach is a proposition, and the proposition is this: that social arrangements should be evaluated according to the extent of freedom people have to promote or achieve functionings they value. If equality in social arrangements is to be demanded in any space - and most theories of justice advocate equality in some space - it is to be demanded in the space of capabilities (Sen, 1992, 1996b).

\section{Poverty as deprivation of capability}

Understanding and interpreting of poverty is controversial during the process of global development. Along with the economical and social development, poverty enjoys variety of dimensions, it varies from absolute poverty to relative poverty, from material poverty to broaden mental poverty concerning feeling oneself inferior, lacking of fundamental engagement in public policy, vulnerability of disdain ,infringement and insulation, due to the deprivation of entitlement and capability.

Sen utilizes the capability approach to understand the essence of poverty, demonstrates that the informational base of assessment of poverty is that our evaluations and policies should focus on what people are able to do and be, on the quality of their life, and on removing obstacles in their lives so that they have more freedom to live the kind of life that, upon reflection, they have reason to value and cherish. Sen's capability approach is widely utilized by the UN and World Bank as an inspiring approach of poverty evaluation.[18] As for Sen, poverty is more than lower income, the essence of poverty is deprivation of capability of the poor and needy. The deprivation of capability is the real poverty, it includes various kinds of poverty of human life, it includes not only lower-income poverty but non-lower-income poverty.[11][15] The perspective of capability approach reminds us that we should put emphasis not only on the connection of income poverty and deprivation of capability, but on the ultimate purpose of anti-poverty. To highlight what is mean and what is end is of great importance. Perspective of poverty as deprivation of capability turns the focus of poverty from mean to end, and to the freedom which is essential for the realization of the end. Poverty means the poor and needy are lack of capability to obtain and enjoy real life. In order to diminish the poverty and promote individual freedom and self-fulfillment, it is fundamental to lift the capability of the poor and needy. To integrate promotion of capability of the poor and needy into the process of global development, it is helpful for developing country to put the slogan of human rights into practice and build a harmonious and sustainable society.

\section{Correlation of poverty and corruption}

In many countries, Corruption is both the cause of poverty and failure of capability and the consequence of poverty and failure of capability. Drawn from the efforts we pay for anti-poverty from past to present, corruption is an enduring obstacle we have to face up to during the process of social and economic reform and development. Corruption penetrates into government, private sector and civil society, it misleads political decisions, distorts fiscal budgets, disturbs policy implementation, and ultimately impinges upon the direction of development. The moment public and private apartments rent-seeking, corruption will deprive the capability, especially political engagement of citizens. As the bottom of the chain of corruption, the poor lose not only the protection and aid of government, but inferior public services and goods. Meanwhile, corruption is the side-product of poverty and deprivation of capability. The poor and needy will suffer from dual ostracism in the country where corruption as rule of game. Under the circumstance of corruption, wealth is plundered, inequality of income is even serious, the capability of the poor is deprived. The efficiency of the public administration and the capacity of serving the poor and needy is even worse. As for the poor, it will lead to freezing of development. The poor had to get public service by any kind of bribery and other illegal methods. As for the nation, all of these will accumulate the power of destruction, the 
corruption is getting even worse, the process of development is freezing, the capacity to eliminate poverty and to promote capability is getting down. Just as the words from the World Bank: corruption is the No.1 difficulties in dealing with poverty.

When the corruption comes, the most important power of anti-poverty, such as accountability of politics, transparency, and openness are badly damaged. Poverty does not simply mean the decline of income or the level under the average income. [6]Poverty is a phenomenon of polyhedron, only enjoying the capability and civil rights can individual achieve free and total development. However, corruption ruins the basement of development, infringes individual capabilities and human rights, especially breaks the institutions protecting human rights. The country where passing the budget without negotiating with the mass will reinforce the unfairness of development and the deprivation of capability. The political, economical and social entitlements of the mass were deprived and they were lost in morass.

Corruption is the heavy tax for the poor, it draws resources from the vulnerable families. People have no money to bribe will exclude from the main stream of the society. Due to vulnerability, the poor without capability have no choice but bribery. Otherwise, they will exclude from the process of development. Only integrating promotion of capability of the poor into anti-corruption can we achieve effectiveness of anti-corruption, especially for the country lacking of restriction of power. The inequality of political, economic and social capability of the mass will lead and add up to serious corruption and poverty. The strategy of anti-corruption for the poor must conclude the essentials protecting civil rights and promoting capabilities of individuals, otherwise, it will ultimately suffer from failure.

\section{Promoting capability in order to anti-corruption and poverty}

Anti-corruption and poverty means to overcome the obstacles which prevent people from promoting their capabilities especially the capability of engagement, otherwise, people can't hold the capability of monitoring the government. Although majority of the developing countries declare that the poor and vulnerability have both equal opportunity of engagement and civil rights, in fact, they were regularly kept away from these basic human rights. The interest groups can manipulate national political institutions and parties by taking advantage of corruption in order to freeze the process of development. By doing so, They can infringe the capability and entitlement of the poor freely, the poor will fall into distress and helplessness. The strategy of anti-corruption and poverty during the process of development must scrutinize both the failure of capability caused by the political, economic and social restricted policy of the poor and the social and situational backgrounds causing the failure above.

Reinforcing accountability and engagement of politics is of great importance for promoting the capability of the poor and advancing the efficiency of anti-corruption and poverty. National politics is empowered and regulated by the people, the government must be accountable and responsible. [24] The corruption of public and private sector spoiled and distorted institutions and constitution of a country, it leads to poverty, deprivation of capability and injustice development. Reinforcing accountability of politics would protect the poor in the battle of combating corruption, they are not victims but stakeholders.

In the imperfect and unaccountable mechanism of market economy in developing countries, Too much participation of the government during the process of development causes not agreeable benefits but severe damage. There is no evidence shows that the planned economy is better than the market economy. From the post-war experience of lots of developing countries, a lot of severe failures of development were caused not by market but by government, and the failures of government are far more than the failures of market.

Social exclusiveness limited the capability of the poor and needy, this distorted the goal of anti-corruption and poverty. To fringe the poor is contradictory to the spirit of good governance, this will lead to social conflicts. Social exclusiveness and corruption will severely undermine legitimacy, efficiency of governance and public trust and integrity of government. Due to deprivation of 
capability ,the poor will suffer from vicious circle of corruption and inequality. To advance the capability and engagement of the poor is good for promoting the dignity of the poor and vulnerability during the process of development. By strengthening collective partnerships of peers involved, It will be more effective to integrate multi-stakeholders in the process of combating corruption and poverty.

In order to enhance the efficiency of anti-corruption and poverty, we should focus more on promotion of capability. From capability approach, to keep the poor alive is not the ultimate goal of modern anti-poverty activity. It is of even great importance to calculate and promote the capability of the poor. By enhancing their capability, the poor could integrate themselves into the main stream of society. We should insist anti-poverty on both physical and mental aspect. From capability approach, there are a lot of functionings and capabilities we have reason to cherish, poverty as capability failure is an integrated approach.[7] The poor suffer from not only the shortage of materials but psychological and mental frustrations and depressions. Anti-poverty needs more psychological and mental help for the poor and needy, especially the respect of dignity of the poor .China is on the way of transferring development, it is even urgent to promote the capability of the mass, especially for the poor and needy. Only by doing this can sustainable development come true.

\section{Conclusion}

Currently, the literature on the capability approach is scattered. Amartya Sen's writings have been gradually developed over the years, moreover, the literature on the capability approach has been growing exponentially in recent years. This paper has therefore endeavored to present the core conceptual aspects of Sen's capability approach in an attemptative way. It discusses and delivers the conception of capability approach. The core of development is to face up with the challenge of the issue of poverty, which directly is associated with the ultimate goal of social and economic development. If the poverty has not been properly handled, development will be inefficient and unsustainable. This paper also utilizes the capability approach to understand the essence of poverty, demonstrates that the informational base of assessment of poverty is that our evaluations and policies should focus on what people are able to do and be, on the quality of their life, and on removing obstacles in their lives so that they have more freedom to live the kind of life that, upon reflection, they have reason to value and cherish. This essay illustrates the inter-relationship of capability, poverty and corruption, it demonstrates that corruption is both the cause and the consequence of poverty and the failure of capability. When there corruption comes, the main power of anti-poverty, such as political accountability, transparence ,engagement and openness are all spoiled and even wiped off. Political accountability, transparence, engagement are of great importance to both anti-corruption and poverty and promotion of capability. Economic aid for the poor should be reinforced by fostering and promoting the capability of the poor and needy, so that the aim of eliminating poverty and corruption can be achieved. China is on the way of transferring development, it is even urgent to promote the capability of the poor and needy, so as to speed up the efficiency of anti-corruption and poverty. So what is the way of anti-corruption and poverty ahead? Researchers and practitioners seem quite determined to put the capability approach to work globally during the process of development in the near future.

\section{References}

1. Alkire S.Valuing Freedoms. Sen's Capability Approach and Poverty Reduction, New York: Oxford University Press, 2002.

2. Arrow K. J. Amartya K. Sen's Contribution to the Study of Social Welfare, Scandinavian Journal of Economics, 1999(2):163-172.

3. Clark D.A. Sen's Capability Approach and the Many Spaces of Human Well-being, Journal of Development Studies, 2005(8): 1339-1368.

4. Comim F. Operationalising Sen's Capability Approach, presented to the Second Annual Capabilities Conference: Promoting Women's Capabilities: Examining, 2001. 
5. Crocker D, Robeyns I. Capability and Agency. In Morris C (ed) Amartya Sen. Cambridge: Cambridge University Press, 2010: 60-90.

6. Estlund D. The Best and the Rest: Optimizing and Comparing in Theories of Justice. Symposium on Amartya Sen's the idea of justice, Rutgers University, 2011: 15-16.

7. Gaus G. Social contract and social choice. Symposium on Amartya Sen's The idea of justice, Rutgers University, 2011(4) : 15-16.

8. Nussbaum M. C. Capabilities and human rights, Fordham Law Review, 1997(66): 273-300.

9. Nussbaum, M. C. (2003a) Capabilities as fundamental entitlements: Sen and global justice, Feminist Economics,9, pp. 33-59.

10. Pettit, Ph. (2001) Capability and freedom: a defense of Sen, Economics and Philosophy,17:1-20.

11. Pogge, T. (2002) Can the capability approach be justified? Philosophical Topics, 30(2): 167-228.

12. Robeyns, I. (2006) The Capability Approach in practice, Journal of Political Philosophy,14(3): 351-376.

13. Sen, A.K. (1980) 'Equality of what?', in S. McMurrin (Eds.), The Tanner Lectures on Human, Values, Salt Lake City, Utah.

14. Sen, A.K. (1984a) The living standard, Oxford Economic Papers, 36, pp. 74-90.

15. Sen, A.K. (1984b) Rights and capabilities in Resources, Values and Development, Harvard, University Press, Cambridge, MA.

16. Sen, A.K. (1985b) Commodities and Capabilities, Elsevier, Amsterdam.

17. Sen, A.K. (1993a) Capability and well-being, in A. Sen and M. Nussbaum (Eds.), The Quality of Life, Clarendon Press, Oxford, pp. 30-53.

18. Sen, A. K. (1999a) Development as Freedom, Oxford University Press, Oxford.

19. Sen, A. K. (1999b) Reason before Identity, Oxford University Press, Oxford.

20. Sen, A.K. (2002a) Rationality and Freedom, Belknap Press, Cambridge, MA.

21. Sen, A.K. (2005a) 'Human rights and capabilities', Journal of Human Development, 6(2), pp. 151-166.

22. Sen, A.K.(2006) Identity and Violence: The illusion of Destiny ,Oxford University Press, Oxford.

23. Sen A K. (2009) The idea of justice. Harvard University Press, Cambridge

24. Streeten, P. (1995) Human development means and ends, UNDP Roundtable on Global Change Paper 6, United Nations Development Program, New York.

25. Williams B (1980) Justice as a virtue. In: Rorty A (ed) Essays on Aristotle's ethics. University of California Press, Berkeley, pp 189-19 